\title{
Bridging the Gap between University and Industry: Efforts Made at Faculty of Engineering - Rabigh - Saudi Arabia
}

\author{
Abdullah Al-Shehri ${ }^{, 1}$, Mostafa A-b Ebrahim ${ }^{, 2}$, Hani Shafeek ${ }^{2}, 3$, Mohamed Fekry Soliman ${ }^{, 4}$, \\ Mohamed Helmy Abdel-Aziz $*$;, 5 \\ ${ }^{2}$ Faculty of Engineering, King Abdulaziz University, Rabigh 21911, Kingdom of Saudi Arabia (KSA) \\ ${ }^{1}$ Electrical Eng. Dept., King Abdulaziz Univ., Rabigh, KSA, ${ }^{2}$ Civil Eng. Dept., Assuit Univ., Egypt, ${ }^{3}$ Faculty of Industrial \\ Education., Suez Canal Univ., Egypt ${ }^{4}$ Civil Eng. Dept., Aswan Univ., Egypt, ${ }^{5}$ Chemical Eng. Dept., Alexandria Univ., \\ Egypt. \\ * Corresponding author: E-mail: helmy2002@ gmail.com
} Phone: 00966540853623

\begin{abstract}
For a long time collaboration between Universities and industry has been existed, but the rapid increase of global knowledge has strengthened the demand for strategic relationships that go beyond the conventional funding of research projects. The role of the university's research should be developed in the coming centuries to play an important role in industrial and in turn economic growth. To make the chemistry work, both sides should overcome the communications and the cultural divide that tends to impair university - industry relationships of all categories and undercut their potential. Faculty of Engineering Rabigh (FER) is strategically located around major industries and facilities like Petro Rabigh, desalination plant, steel fabrication and cement industries. This makes FER a nucleus to solve technological problems for all these industries. A number of efforts have been made at FER to collaborate with these industries by mutual reciprocal visits of university and industry personnel as well as student internships. It is aimed to solve short term and long term technological issues at the industrial units. This will not help the local knowledge base and skills to improve but bring confidence and trust between two partners. It is to be remembered that innovation does not happen in a vacuum: A context the economy, society and policy - shape how easy or hard it is to innovate. In this context the role of government is also very important to create legislations that make the university - industry relationship as a win-win situation.
\end{abstract}

Keywords: University-industry relationship; knowledge base; Research University; technological issues; legislations.

\section{Introduction}

The role of the university has become very dynamic and entrepreneurial in this century. There are models and indicators available to judge entrepreneurial orientation of the university. University and industry (UI) are joining hands to explore the new horizons of opportunities through research and development [1]. This mutual relationship benefits both the organizations and strengthens a country's economy by industrializing the researched products. Therefore, academia-industry relationship has itself become a subject of research and is continually being refined and consolidated. The public-private relationship between the universities and industry is examined to study the outcomes of cooperation. One of such bibliometric study is carried out to analyze the relationship between the universities with the local industries. Sometimes the number of patents coauthored by university and industry personnel is set as a quantitative indicator of the effectiveness of collaboration. An interesting trend indicated by Veugelersa and Cassiman in an analysis of the Belgium manufacturing is that mostly chemical and pharmaceutical industry which involves fewer ricks is more likely to have Research and Development (R\&D) ties with a university. A study of the R\&D cooperative agreements between Spanish firms and organizations of research reveals that the previous links, the main keys for the success of such companies are the definition of aims and commitment which also confirmed by a study of a similar nature in European universities [2]. A research describes an interesting aspect of knowledge spill over from university to industry and reveals that the informal contacts between university and industry are greater than that of formal contacts. Government polices play an important role in establishing of universityindustry (UI) relationships. 
Korea has studied the triangle of university-industrygovernment relationship and came up with a result that Korea is in a transitional phase in industrialization knowledge and national innovation system. In Portugal, Triple helix model was applied at the University of Coimbra to study the effectiveness of the trilateral relationship of university-industry and the government and realized that the relationships developed by the university made a mesh of networks and hybrid organizations[3]. Hence, there have been serious efforts for the establishment of UI relationships and a number of empirical models and performance indicator are available in addition to the policy discussions. Government policies play a vital role in strengthening this UI relationship. The number of patents jointly authored by the university and industry is a straightforward indication of the degree of relationship between both the organizations [4].

\section{University - industry relationships in Saudi Arabia and gulf region}

The Saudi Arabia's future innovation platforms cannot be isolated from the changes in the Saudi economy that take place nowadays. The Saudi economy is known for a long time for its chronic dependence on the Saudi's natural resources. Saudi Arabia is one of several countries that its economy affected by its natural-resource wealth in many ways. The factors affecting the economy of these countries include, but not limited to, the research and development (R\&D) levels. The Saudi industry has been affected by the continuity of the deep reliance on natural resources for the past decades. The industry landscape has been dominated by large corporations which include Saudi Basic Industries (SABIC) and Saudi Aramco, which has the monopoly of the oil development upstream. SABIC is the largest non-oil company within the Middle East and currently considered as the seventh of the world's largest petrochemical producer. Although there are potential pockets of innovation, Saudi Arabia's development keeps stable in the investment stage [5].

Universities in Saudi Arabia should swiftly develop and adapt to new roles. They should also promote young entrepreneurs, encourage new ideas and methodologies, support financially and mentor them and cooperate with surrounding industries to develop knowledge into commercial products. Academic entrepreneurship is a main factor to hit the target of economic prosperity. The developing economies of the world nowadays depend on the human capital and Knowledge-based societies. This means that the current role of academia is facing more challenging than that was before three decades ago. Apart from creating knowledge and doing research, universities must play a pivotal role in developing the economy. Because of this structural shift both in the US and Europe, universities are attracting a lot of researchers thus opening many opportunities for entrepreneurs to bring their dreams to reality. It was the co-evolution of Stanford University and Silicon Valley way back in the 1980s, which is still considered a role model for universities across the globe to contribute positively toward economic development. Their close collaboration has created companies like Yahoo and Google that has brought thousands of jobs and generated billions of dollars.

If we analyze the factors that lead to the success of Silicon Valley, we can pinpoint entrepreneurial attitude, legal support, venture capital, space for setting up cluster of companies, educated workforce, research labs, risk taking, allowance for failure and celebration for success. The same basic model is now adopted and modified as per local customs and culture by other countries to create Silicon Valley type environments to ensure that universities can perform their new mandate effectively. Hence, academic entrepreneurship is not only responsible for creating knowledge but they go one step further and take various initiatives to facilitate the conversion of this knowledge through technology transfer processes into market environments. In Saudi Arabia, similar types of initiatives have already been announced by various universities; King Saud University (KSU), King Fahd University of Petroleum and Minerals (KFUPM), King Abdullah University for Science and Technology (KAUST), and King AbduAziz City for Science and Technology (KACST), KFUPM launched Dhahran Techno Valley, KSU launched Riyadh Techno Valley, KACST initiated Al Badir for Biotechnology companies, and recently KAUST launched its full-fledged economic development initiative.

Despite these initiatives that started a few years ago, the progress of incubating and turning ideas into reality has been slower than expectations. This is understandable as the corporate world and the academia have totally different objectives of their existence and common ground must be found. Companies always work toward advancing the interests of shareholders and increase their wealth while the academia focuses on developing the quality of education and research. On one hand, companies do not understand the internal process of the academia to convert a lab idea into a product that generates revenues. At the same time, universities must align their strategy to meet their entrepreneurial goals. Universities need to take a multipronged approach. They should introduce changes to the 
curriculum so engineers and scientists can start thinking toward entrepreneurship and develop close links with industry and ask the leading companies to set up their satellite offices in the vicinity of the campus. These steps would reduce the time spent on reviewing the patenting process and licensing, hire separate and specialized staff for technology transfer offices (filing patents, marketing and handling postlicense relationship with industry partner). New policies are required to reward those who are able to raise revenues for universities and finally link with venture capitalists. Licensing deals or equity deals with new companies that deploy university technology would boost revenues. It is so earnest to accommodate that the whole process of ideas, patents and final commercial production may take several months or years.

Academic entrepreneurship is a key to achieving economic development. Saudi Aramco has already launched its Wa'ed Program, which will be a boon for young entrepreneurs. It is working closely with universities to promote new ideas and provide necessary funding to university projects that impact the Kingdom's economy. Wa'ed also accepts direct applications from young entrepreneurs. In brief, if the academia in Saudi Arabia wants to play an active role in a company's development, close collaboration between industry and academia is the need of the hour. At the same time, universities need to review and improve their internal processes so they can make a significant impact on the country's economy.

\section{Collaborative research between universities and industries}

Nowadays, universities are holding the key to the development of the regional economic and cluster formation because the economies of the industrial countries become more knowledge-based. The Organization for Economic Cooperation and Development (OECD) defines the knowledge-based economies as "one in which the production, use, and distribution of knowledge and information are critical to the process of economic growth" [7]. It is not surprising that the university's role is central to the emerging knowledge-based economies.

Since the economies of the industrialized countries have become more knowledge-based, universities have become viewed as important players in regional economic development. A survey in the "Economist" suggested the concept of the knowledge-based economy serves to "portray the university not just as a creator of knowledge, a trainer of young minds, and a transmitter of culture, but also as a major agent of economic growth: the knowledge factory, as it were, at the centre of the knowledge economy" [6].
When thinking about developing new technologies, universities bring valuable resources to the table. Among these are: research - basic and otherwise; access to funding; access to the latest, most up-to-date knowledge base; access to physical assets (i.e. technology, specialized equipment, etc.) and more.

Universities that spin off research to companies to create viable products and services is a win-win situation. It sounds easy but can be difficult to achieve, which means the full potential of some technologies are never fully realized.

Effective knowledge sharing between public science and industry is recognized as one of the pathways towards the knowledge based society and has been pointed out by the European Commission as one of the main features of the European research area [8]. Relationships between universities and industry can take a number of different forms such as: [9, 10].

- Companies fund research projects at public research organizations;

- Development of joint research projects with participants from the firm and the university;

- Co-publications resulting from joint research projects;

- Collaborative technology development resulting in inventing and/or assigning competent;

- University scientists working at firms;

- Firm's employees working within universities;

- Companies license university patents;

- University scientists undertaking short term consultancies;

- Participation in formal and informal networks. Co-publishing between a university and industry must be understood on the background of the university publishing specialization and also the role the university plays in the national context. 'Top universities' are important players in relation to university-industry co-publications. One of the problems with the use of the data on co-publications and patenting alone is the lack of detailed evidence on how good a proxy they are for measuring university-industry linkages.

It is important for university professors and the students to carry out researches related to the industry and publish their results because the dissemination of knowledge is the essence of academic research. This is the main way for the professors' peers to judge professors achievement, the advancement and tenure, and obtain future grants and recognition. For students, it is essential to publish their research results to obtain post-doctoral positions and jobs. Some compromise has to be worked out to make the industrial partners out of fear that publication may endanger their intellectual property that may arise 
from such collaboration, It takes usually a period of 30-60 days for the company personnel to examine the manuscript and determine if the research results contain any patentable items or not and, if so, the writing of the patent starts [11].

Table 1 shows the results of a questionnaire about to what extent do universities and business collaborate on R\& D in the world's countries. It shows the University/industry research collaboration the global innovation index. Average answer to the survey question $1=$ do not collaborate at all; $7=$ collaborate extensively.

Table 1, University/industry research collaboration the global innovation index 2012

\begin{tabular}{|c|c|c|c|c|c|c|c|c|c|}
\hline Rank & Country/Economy & Value & $\begin{array}{c}\text { Score } \\
(0-100)\end{array}$ & $\begin{array}{c}\% \\
\text { Ran } \\
\text { k }\end{array}$ & Rank & Country/Economy & Value & $\begin{array}{c}\text { Score } \\
(0-100)\end{array}$ & $\begin{array}{c}\% \\
\text { rank }\end{array}$ \\
\hline 1 & Switzerland & 5.78 & 79.61 & 1.00 & 41 & Chile & 4.09 & 51.47 & 0.70 \\
\hline 2 & United Kingdom & 5.75 & 79.21 & 0.99 & 42 & Mexico & 4.04 & .50 .67 & 0.69 \\
\hline 3 & USA & 5.71 & 78.51 & 0.98 & 47 & India & 3.82 & 46.97 & 0.65 \\
\hline 6 & Singapore & 5.47 & 74.48 & 0.96 & 48 & Brunei Darussalam & 3.80 & 46.70 & 0.64 \\
\hline 10 & Qatar & 5.27 & 71.17 & 0.93 & 53 & Oman & 3.78 & 46.29 & 0.61 \\
\hline 11 & Canada & 5.20 & 70.05 & 0.92 & 55 & Tunisia & 3.75 & 45.79 & 0.59 \\
\hline 12 & Germany & 5.16 & 69.29 & 0.92 & 63 & Panama & 3.64 & 43.93 & 0.53 \\
\hline 13 & Australia & 5.15 & 69.21 & 0.91 & 66 & Pakistan & 3.56 & 42.71 & 0.51 \\
\hline 15 & Japan & 5.06 & 67.61 & 0.89 & 70 & Sri Lanka & 3.49 & 41.55 & 0.48 \\
\hline 20 & Malaysia & 4.91 & 65.12 & 0.86 & 71 & Turkey & 3.49 & 41.48 & 0.47 \\
\hline 22 & Hong Kong (China) & 4.74 & 62.27 & 0.84 & 76 & Italy & 3.48 & 41.30 & 0.43 \\
\hline 24 & Korea, Rep & 4.66 & 60.99 & 0.83 & 84 & Bahrain & 3.33 & 38.91 & 0.37 \\
\hline 25 & South Africa & 4.62 & 60.30 & 0.82 & 90 & Iran, Islamic Rep & 3.25 & 37.50 & 0.33 \\
\hline 26 & Portugal & 4.6 & 60.00 & 0.81 & 92 & Ghana & 3.23 & 37.21 & 0.31 \\
\hline 27 & Saudi Arabia & 4.56 & 59.27 & 0.8 & 102 & Kuwait & 3.16 & 36.03 & 0.23 \\
\hline 28 & China & 4.53 & 58.82 & 0.8 & 110 & Jordan & 3.07 & 34.48 & 0.17 \\
\hline 35 & UAE & 4.21 & 53.43 & 0.74 & 111 & Romania & 3.00 & 33.27 & 0.17 \\
\hline 36 & Brazil & 4.2 & .53 .41 & 0.73 & 121 & Bangladesh & 2.63 & 27.20 & 0.09 \\
\hline 37 & Thailand & 4.15 & 52.57 & 0.73 & 122 & Egypt & 2.60 & 26.60 & 0.08 \\
\hline 38 & Indonesia & 4.13 & 52.15 & 0.72 & 133 & Yemen & 1.51 & 8.44 & 0.00 \\
\hline
\end{tabular}

SOURCE: World Economic Forum, Executive Opinion Survey 2010-2011

\section{Faculty of Engineering - Rabigh}

Faculty of Engineering in Rabigh (FER) was established in 2009. It belongs to King AbduAziz University which main campus located in Jeddah city. FER consists of five engineering departments; Electrical, Mechanical, Industrial, Chemical and Materials, and Civil. FER was established away from the university main campus to serve the surrounding region in Rabigh city. Rabigh is a famous city with its historical heritage located on the western coast of Saudi Arabia (Red Sea). It lies within Makkah Province. Rabigh has several industries such as petrochemical, cement, desalination, electricity and attached to King Abadullah Economic City. It is also located $150 \mathrm{~km}$ south to Yanbu Industrial city, the largest ndustrial city in the region. Figure 1 shows the locations of Rabigh city and FER.
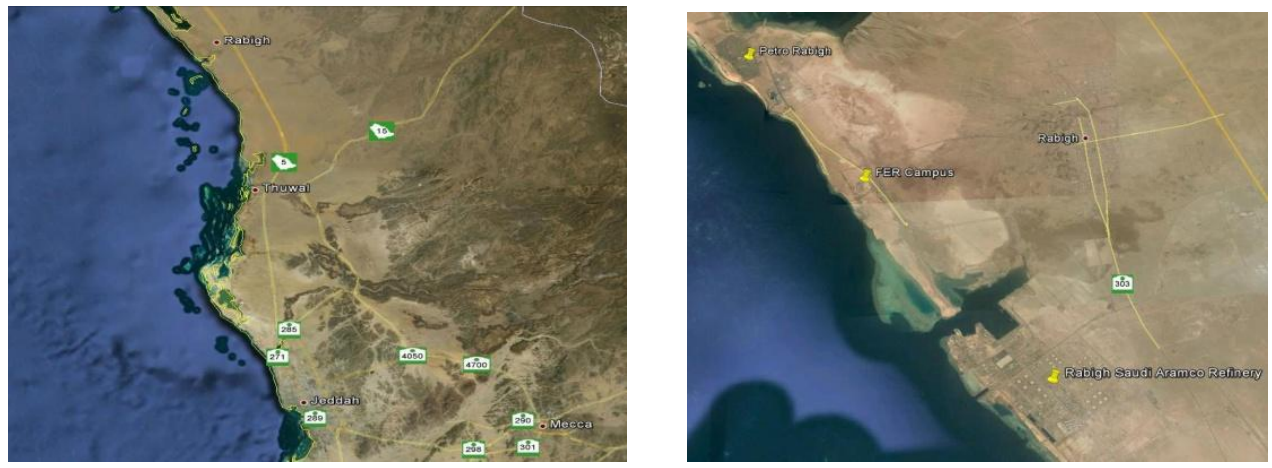

Fig. 1, Rabigh City and FER locations. 


\section{FER-Gab Bridging Model}

Faculty of engineering in Rabigh (FER) was established in 2009. During this short period a significant contact has been done between the FER and the industrial sector through a combination of factors. FER is strategically located in the centre of major industries. It is also closed to Yanbu Industrial City, the largest petrochemical Industrial City in the region. This makes FER a nucleus to solve technological problems for all these industries. As a new Engineering Institution, a real challenge was facing the Faculty to approach its local and surrounded environment in unusual way. The uniqueness of FER as a single and developing engineering school in its region made it possible to establish its gab bridging model to approach the local industrial community. The effective communications and usage of its internal personnel expertise are the key elements for its model to reach and drag the local industry. One of the main challenges of FER is to approach its surrounding community and building the necessary relations. A new industrial relations and community service unit (IRU) was formed to achieve the FER strategy. A significant contact has been done between the FER and the industrial sector through efforts and activities through this unit. We should say that role of IRU unit combined with the additional efforts made by the departments and is the core element of FER gab bridging model as shown in figure 2 .

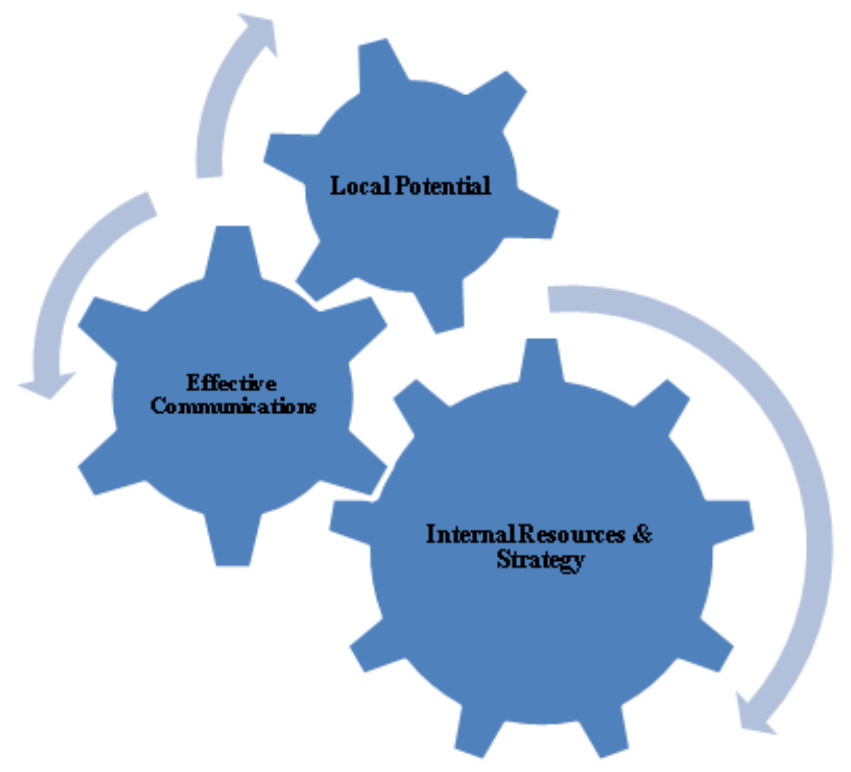

Fig. 2, FER combination of factors model

The FER combination of factors model consists of three main axes, namely:
A. Internal resources and strategy
B. Local potential
C. Communications

The internal resources include several items such as, staff members, expertise, knowledge, and industrial units.

The local potential depends on the surrounding and nearby industries. The surrounding industries include, but not limited to, the following companies:
$>$ Saudi Aramco

$>$ SABIC

$>$ Petro-Rabigh

$>$ Halliburton

$>$ Cement Arabia

$>$ Electricity Co. in Rabigh

$>$ SAFOLA

$>$ PETROMAINT

$>$ Al Rajhi steel

$>$ Desalination plant

$>$ King Abdullah Economic City 
Communications between the FER and the surrounding industrial companies was made via;

$\Rightarrow$ Reciprocal Visits

$\Rightarrow$ Personal contacts

$\Rightarrow$ Consultative committee

$\Rightarrow$ Training courses

$\Rightarrow$ Graduation projects

$\Rightarrow$ Summer training

$\Rightarrow$ Engineering day

$\Rightarrow$ Applied research

\section{Activities used in the implementation of the FER model}

Since the inception of FER, it has played its active role in collaborating and supporting the industries around Rabigh region. A number of activities have been done to promote dissemination of knowledge.

\subsection{Establishing a consultative committee}

One of the important fruitful results of cooperation between the FER and the industrial sector is the formation of consultative committee. Figure 3 shows the combination of the committee members.

The main tasks of this committee are:

(1) Strengthening the link between the college and the community

(2) Contribute to the support the scientific researches

(3) To express an opinion on the curriculum

(4) Proposal of development projects and programs to serve students

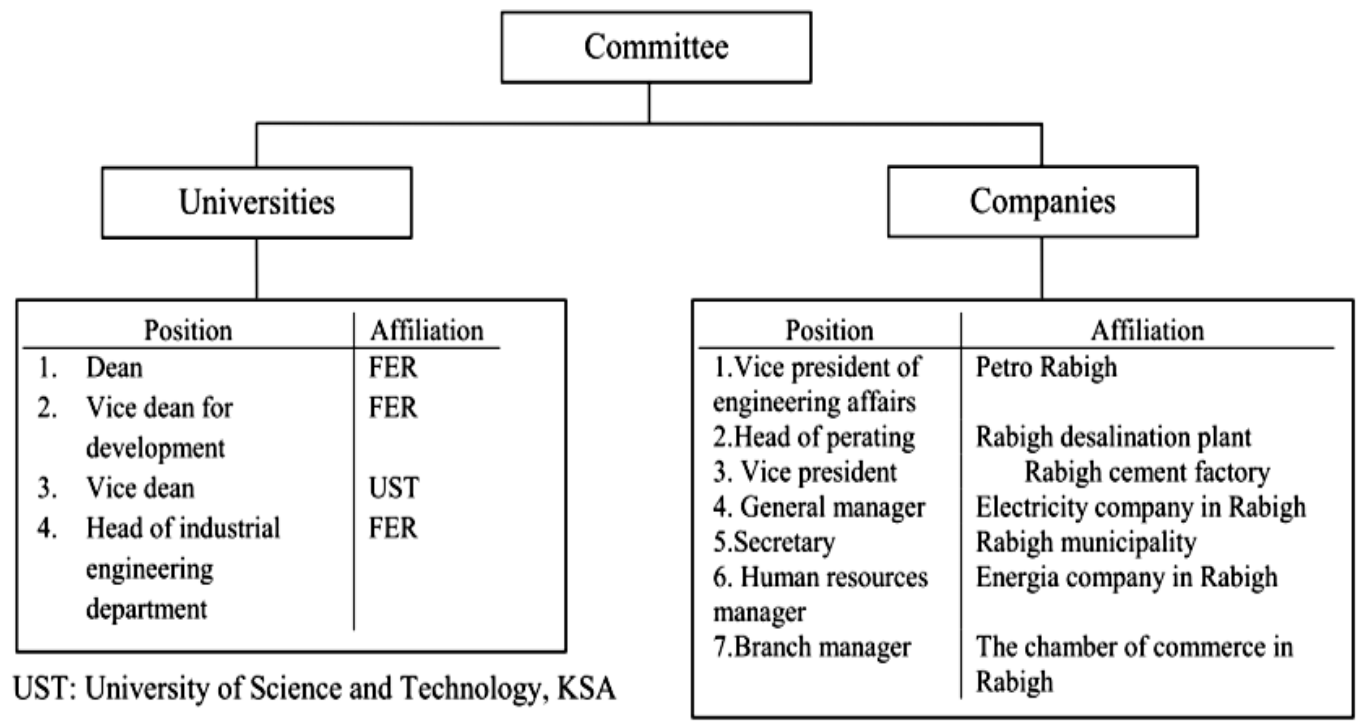

Fig. 3, Consultative committee members

\subsection{Training courses}

In the year 2012 - 2013, FER offered extensive training courses for engineers in the industrial sector as listed in table 2. The courses have been evaluated and have met the desirability of the trainees. The evaluation form included several points among them; the course contents, course time, facilities used, and familiarity of the trainer with the course contents. The number of courses offered by the FER supposed to be increased in the next years according to the recommendations and the needs of the companies.

\subsection{Summer training for students}

In collaboration with the industrial sector the FER has established mandatory training programs for students after completing the required credit hours while the FER is in continuous communication with the industrial companies to provide more training opportunities according to the specialization of the student. The students are evaluated during the training period by supervisors from the FER and the companies. The student training programs help in linking academic knowledge and industrial applications, which helps to graduate up-to-market engineers. Figure 4 shows the distribution of students on the surrounding industrial companies in 2012. The 
number of students supposed to be increased in the next years according to the offers of the companies. At the end of each year a regular annual meeting is organized with members from the companies in the Table 2, Training courses offered by the FER in 2012 -2013 so-called the Engineering Day. All students are invited and the companies offer their training and job opportunities.

\begin{tabular}{|c|c|c|c|}
\hline Training course & Objectives & Companies & $\begin{array}{c}\text { No. Of } \\
\text { Trainers }\end{array}$ \\
\hline Safety and loss prevention & $\begin{array}{l}\text { The main objectives are: to introduce the } \\
\text { concept of process safety as it takes place for } \\
\text { all industrial processes, explain the degree of } \\
\text { hazards, know the fundamentals of HAZOP } \\
\text { study and understand the applications along } \\
\text { with the software program. }\end{array}$ & \multirow{3}{*}{$\begin{array}{l}\text { Petro-Rabigh } \\
\text { Arabia Cement } \\
\text { Desalination } \\
\text { plant }\end{array}$} & \multirow{3}{*}{26} \\
\hline $\begin{array}{l}\text { Design and Operation of } \\
\text { Heat Exchangers }\end{array}$ & $\begin{array}{l}\text { Give an overview on the different types and } \\
\text { uses of heat exchangers. } \\
\text { Application of the basics of heat transfer in } \\
\text { heat exchangers design and selection for a } \\
\text { specific process } \\
\text { Heat exchangers problems }\end{array}$ & & \\
\hline $\begin{array}{l}\text { Introduction to CFD and its } \\
\text { Importance in Industry }\end{array}$ & $\begin{array}{l}\text { Starting with the basic principles and science } \\
\text { of CFD, the scope of the workshop extends to } \\
\text { the applications of commercial CFD codes } \\
\text { and meaningful interpretation of results. }\end{array}$ & & \\
\hline
\end{tabular}

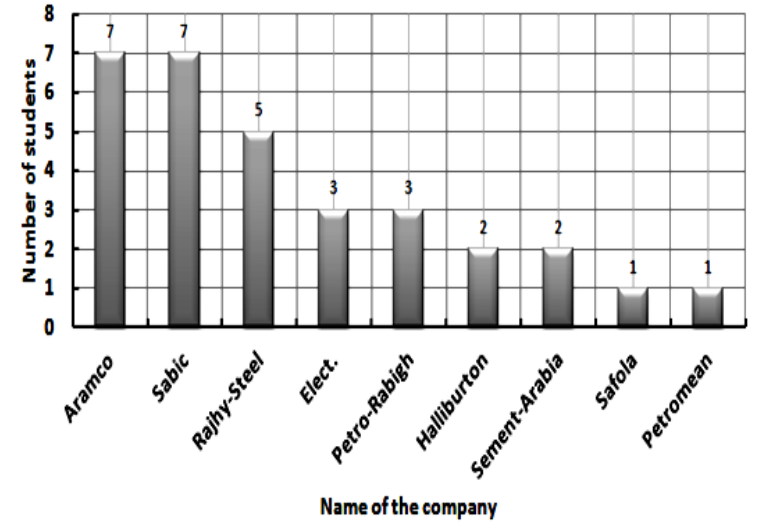

Fig. 4, FER students training distribution on the industrial companies in Saudi Arabia in 2012

\subsection{Applied research activities at FER}

The applied research activities have a higher priority in FER. It is an effective way to transfer knowledge from the universities to companies [12-14]. The staff members at FER are in continuous contact with the industrial companies. Funded research projects are offered by the university and the companies as SABIC and SAUDI ARAMCO. Figure 5 shows the publications of FER till April 2013. Figure 6 shows the distribution of funded research projects till the same date. One of the most important criteria for accepting projects for funding is its validity for application in industry.

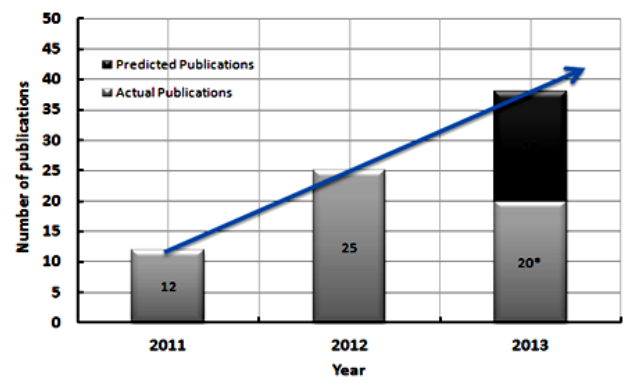

Fig. 5, FER publications till April 2013

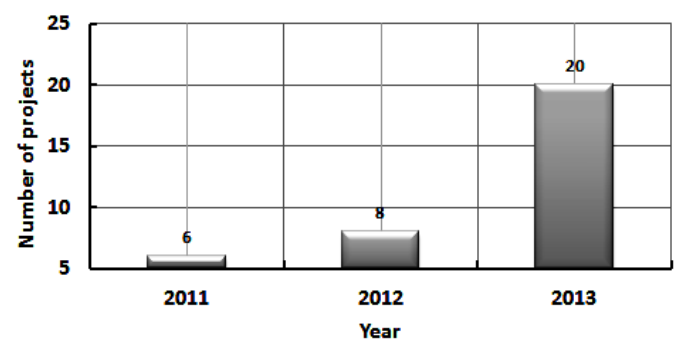

Fig. 6, FER funded projects till 2013 


\subsection{Reciprocal visits}

The FER has configured an Industrial Relations Committee from the faculty members. The function of this committee is to support communication between the university and the industrial sector through visits to/from the companies to know their requirements and display them to the other members of the faculty.

\section{Obstacles to strengthen the relationship between universities and the industrial sector}

There is no doubt that there are some obstacles and difficulties that stand in the way of achieving the hoped cooperation between FER and the industrial sector. The most important obstacles are:

- Some companies depend on their experts and technicians to solve their problems.

- The difficulty in obtaining the required information for research purposes from a lot of companies.

- Preoccupation of the universities by the academic side at the expense of the practical side.

- Universities lack the presence of specialized laboratories to convert the results of scientific research to the initial product (Prototype) before the production phase.

\section{Recommendations}

The leaders of the higher education sector and the leaders in the industrial sector need to strengthen effective partnership between them because of its important effect on the performance and output of both parties. This can be achieved through the help from the both sides in the following:

- Provide universities with the information required for the needs of the companies of specialized human resources, knowledge and skills required in addition to what they need from consulting and scientific research and specialist

- Contribute to the processing of workshops and research centers with equipment, programs and resources necessary to activate its performance

- Provide and facilitate scientific training possibilities for university students during the summer, according to the system and regulations to be agreed upon between the parties

- Contribute to the funding of scientific research in universities

\section{Conclusions}

For a long time collaboration between Universities and industry has been existed, but the rapid increase of global knowledge has strengthened the demand for strategic relationships that go beyond the conventional funding of research projects. Universities in Saudi Arabia should swiftly develop and adapt to new roles. They should also promote young entrepreneurs, encourage new ideas and methodologies, support financially and mentor them and cooperate with surrounding industries to develop knowledge into commercial products. Academic entrepreneurship is a main factor to hit the target of economic prosperity. Saudi industries should launch such programs for young entrepreneurs. It should work closely with universities to promote new ideas and provide necessary funding to university projects that impact the Kingdom's economy. FER should play its pivotal role more aggressively to bring the industry closer to the University.

The importance of strengthening cooperation and partnership between universities and industrial sector lies in the following factors:

- The development of new sources of funding for universities to enable them to activate their academic performance.

- Conduct applied research and scientific training for university students, which develop their practical skills and thus increases the opportunity to enter the market after graduation.

- The development of educational and qualifying plans and postgraduate studies in universities.

- Cooperation with companies to solve their problems and improve their performance, will lead to the exploitation of the universities' potential in the service of economic development in the country.

- Companies obtain their needs of specialized human personnel of the output of the university.

- Preoccupation of universities in the academic side at the expense of the practical side.

Since the FER has been established, it has cooperated with the surrounding industrial sectors through the following activities:

$>$ Reciprocal visits

$>$ Personal contacts

$>$ Establishing Consultative committee

$>$ Training courses

$>$ Graduation projects

$>$ Summer training

$>$ Engineering day 
Applied research

The FER continuing in cooperation with the surrounding industrial sector in strengthening the desired solid and sustainable relationships and partnerships. The performance of the proposed FER bridging gab model has been successfully measured by the results and achievements of the predetermined objectives. A continuous improvement is needed on regular bases in order to enhance the functionality and efficiency of this model.

\section{References}

[1] K. Philpott, L. Dooley, C. O'Reilly, and G. Lupton, "The entrepreneurial university: Examining the underlying academic tensions," Technovation, 31 (4) pp. 161 - 170, 2011.

[2] G. Abramo, C. A. D'Angelo, F. Di Costa, and M. Solazzi, "University-industry collaboration in Italy: A bibliometric examination," Technovation, 29 (6-7) pp. 498 - 507, 2009.

[3] K. Motohashi, and S. Muramatsu, "Examining the university industry collaboration policy in Japan: Patent analysis," Technology in Society, 34 (2): pp. $149-162,2012$.

[4] A. M. Petruzzelli, "The impact of technological relatedness, prior ties, and geographical distance on university-industry collaborations: A jointpatent analysis", Technovation, 31(7) pp. $309-$ 319, 2011.

[5] K. Al-Sultan and I. T. Alzaharah, "AcademiaIndustry Innovation Linkages in the Case of Saudi Arabia: Developing a University-Industry Triple-Helix Framework to Promote Research and Development Collaboration, THE GLOBAL INNOVATION INDEX, Chapter 3, 89 - 95, 2012.

[6] P. David, "The Knowledge Factor: A Survey of Universities", The Economist, 4 October, 1997.

[7] OECD, Special Theme: The Knowledge-Based Economy, In Science, Technology and Industry Outlook, Paris, 1996.
[8] European Commission, "The European Research Area: New Perspectives", (Green Paper) Brussels: Commission of the European Communities, 2007.

[9] J. Calvert, and P. Patel, "University-industry research collaborations in the UK: bibliometric trends" Science and Public Policy, 30 (2) pp. 85 - 96, 2003.

[10] A. Klitkou, M. Gulbrandsen, P. Patel, and S.V. Ledebur, "State of the Art in Researching the Science-Industry-Link: U-Know WP 2.1", Oslo: NIFU STEP, 2007.

[11] A. L. Demain, "The Relationship between Universities and Industry: The American University Perspective", Food Technology and Biotechnology, 39 (3) pp. 157-160, 2001.

[12] M. H. Gübeli, and D. Doloreux, "An empirical study of university spin-off development", European Journal of Innovation Management 8 (3) pp. $269-282,2005$.

[13] L. G. Zucker, M. R. Darby, and J. S. Armstrong, "Commercializing knowledge: university science, knowledge capture, and firm performance in biotechnology", Management Science 48 (1), 138 - 153, 2002.

[14] R. Landry, M. Saïhi, N. Amara, and M. Quimet, 'Evidence On how academics manage their portfolio of knowledge transfer activities", Research Policy 39, 1387 - 1403, 2010. 